\title{
Classifications at Work: Social Categories and Dutch Bureaucracy in Colonial Sri Lanka
}

\author{
DRIES LYNA* and LUC BULTEN* \\ E-mail: d.lyna@let.ru.nl and 1.bulten@let.ru.nl
}

\begin{abstract}
Feeding into current debates on ethnic identities in colonial South Asia, this article questions to what extent Dutch institutions articulated and impacted social categories of people living in coastal Sri Lanka during the eighteenth century. A thorough analysis of three spheres of Dutch bureaucracy (reporting, registering, and litigating) makes it clear that there was no uniform ideology that steered categorisation practices top-down throughout the studied colonial institutions. Rather, the rationale of the organisation as such affected the way people were classified, depending to a large extent on what level of bureaucracy individuals were dealing with, and what the possible negotiation strategies were for the people recorded. Future research should perhaps not ask "when" certain ethnicities were "made up," but strive to understand the process in which they were created, the institutional contexts in which they were recorded, and how changing bureaucratic practices not only articulated, but also transformed, social categories in the long run.
\end{abstract}

Keywords: social categories, bureaucracy, VOC, eighteenth century, Sri Lanka

\section{Identity, Categorisation, and Colonial Bureaucracy in Sri Lanka and South Asia}

The historiography of Sri Lanka in the past decades was and still is significantly impacted by the ethnic tensions and subsequent civil war that erupted in $1983 .{ }^{1}$ Specifically, since then historians, both Lankan and international, have debated the "origin" of the ethnic identities crucial to that armed conflict, most prominently the Sinhala-speaking Sinhalese from the southern regions of the island, and the Tamil-speaking Sri Lankan Tamils from the north. ${ }^{2}$ 
By 2000, and aptly observed by Eric Meyer, the historiographical debate was dominated by three subsequent waves, each proposing a specific cradle for the historical roots of the contemporary ethnic tensions. ${ }^{3}$ Initially scholars mainly identified Sri Lankan struggles with ethnicity as a unique, primordial characteristic of the island; ${ }^{4}$ in the 1980s historians pointed to the orientalist categorisations made by the British when the island was divided between the East India Company (EIC) and the British Crown respectively in the early nineteenth century $;^{5}$ and in the $1990 \mathrm{~s}$, the emphasis was placed on the later British period and the appearance of discourse amongst Sri Lankan nationalists influenced by Western thought on race and ethnicity. ${ }^{6}$

Since the turn of the twenty-first century, these trends in Sri Lankan historiography have received significant criticism. ${ }^{7}$ In short, the critique boiled down to three arguments: too much reliance on theory and discourse, rather than historical practice ${ }^{8}$ too much orin the primordial "wave" - too little emphasis on colonial power and influence, rather than local agency, constant migration patterns, and the dynamics of identity formation; ${ }^{9}$ and lastly an almost complete ignorance of the earlier Portuguese and Dutch periods of colonial rule, which undoubtedly influenced later British policies in Sri Lanka. ${ }^{10}$ Most importantly, however, as was observed by Wickramasinghe in her 2015 Sri Lanka in the Modern Age, it was time to "read [identity] as tangible - not as a practice, but as something that is embodied in practice" and to "reframe the formation of collective identities in Sri Lanka by consideration of the material, institutional and discursive bases." "11 Additionally, in their 2017 volume Sri Lanka at the Crossroads of History, Biedermann and Strathern argued that the island's historiography thus far had remained significantly localised, while maintaining that the early encounters with European colonialism, the island's location at the heart of the Indian Ocean, and its diverse past could offer significant new insights in debates on global history. ${ }^{12}$

Around the same time as Wickramasinghe and Biedermann and Strathern's observations, studies started to significantly widen the scope of research into identity formation and categorisations throughout Sri Lankan's history, with efforts to connect it to broader historiographical questions. Roberts and Strathern for example have pushed back on the nineteenth-century predilection by highlighting Kandyan and Portuguese perceptions of Sinhalese identity. ${ }^{13}$ Sivasundaram observed how colonial knowledge production and subsequent identification processes came in different waves for the different temporal spaces, referring mainly to the difference between the early-to-be-colonised southwestern coastal regions and the independent Kandyan highlands. At the same time he positioned the colonial transitions of Sri Lanka in the context of the Indian Ocean world. ${ }^{14}$ With her work on eighteenth-century Galle, Rupesinghe introduced the Sri Lankan case to the literature on legal pluralism in colonial Asia while revealing how colonial perceptions could be negotiated and influenced by local litigants, suggesting the same could have happened for categories of identification as well. ${ }^{15}$ Several other works have extended beyond the focus on the "classic" social groups of Sinhalese and Tamil, and underlined the histories of largely neglected communities in Sri Lanka of Luso-Africans, enslaved people from East Asia, and Malay exiles. ${ }^{16}$ 
Continuing the momentum initiated by these works, we intend to feed into this debate by structurally exploring the categorisation of local communities during the period of the Dutch East India Company (Vereenigde Oostindische Compagnie, hitherto VOC or the Company). The question is to what extent specific Dutch institutions, as pars pro toto for colonial bureaucracies as a whole, articulated and impacted social categories of people living in coastal Sri Lanka. Moreover we want to highlight how Sri Lanka's history could add to bigger questions regarding identification in colonial South Asia. Maintaining Brubaker and Cooper's assertion that identity in the colonial context is best explored through the study of relational identity - the networks between people and the way they identify themselves vis-à-vis each another - we will look at different forms of VOC bureaucracy and how the (direct and indirect) interactions of specific institutions with local communities shaped the categories used in the resulting documents and archives. ${ }^{17}$

Based on comparable studies regarding (primarily caste-based) identification of communities in other parts of South Asia, we expect these categories were negotiated, contested, rejected, and eventually, accepted. ${ }^{18}$ Moreover, we hypothesise that the interplay of the web of institutions, social norms, and individuals within the colonial society, and the resulting paper reality produced by its bureaucracy, fuelled classification practices, and thus we should see the identification process as a two-sided, dynamic, fluid, and cumulative process.

Specifically, we focus on three articulations of Dutch bureaucracy in the decades directly preceding the British period of rule (roughly 1766-1796), ${ }^{19}$ all varying in degrees of interaction with local inhabitants and their agency in the categorisation effort: reporting, registering, and litigating. Firstly we take a look at the missives or reports sent from the Political Council of Ceylon, which included the governor and eight other political figures from the Company's administration in Sri Lanka, back to the Seventeen Gentlemen (Heren or Heeren XVII) in Holland, the centralised board of the four departments of the VOC. How did the highest political institution of Dutch colonial Sri Lanka communicate about the social realities of the island towards Company officials in the motherland? Secondly, we turn to the Dutch thombo registrations of land, people, and services, fascinating sources which built on earlier Portuguese and even precolonial systems. Preliminary research indicated that categorisation in these registers seems to have been subject to forms of negotiation between the thombokeeper (a Dutch official) and the local inhabitants. Thirdly, court files from civil suits brought before the Dutch Council of Justice in Colombo will be scrutinised as well, to detect the complexities of (ethnic) identification in litigation practices. Previous research indicated that this highly localised court attracted litigants and witnesses from all across the sociocultural and religious spectrum. These court records, and to a lesser extent also the thombos, give us a more direct glimpse of everyday life in the colonial setting and, as Remco Raben recently claimed, allow historians to read "beyond the grain" compared to the political discourse of the more high-end missives. ${ }^{20}$ The continuous comparison of classification practices in these three bureaucratic layers will show us the complex and negotiated reality of identification in eighteenth-century Sri Lanka. 


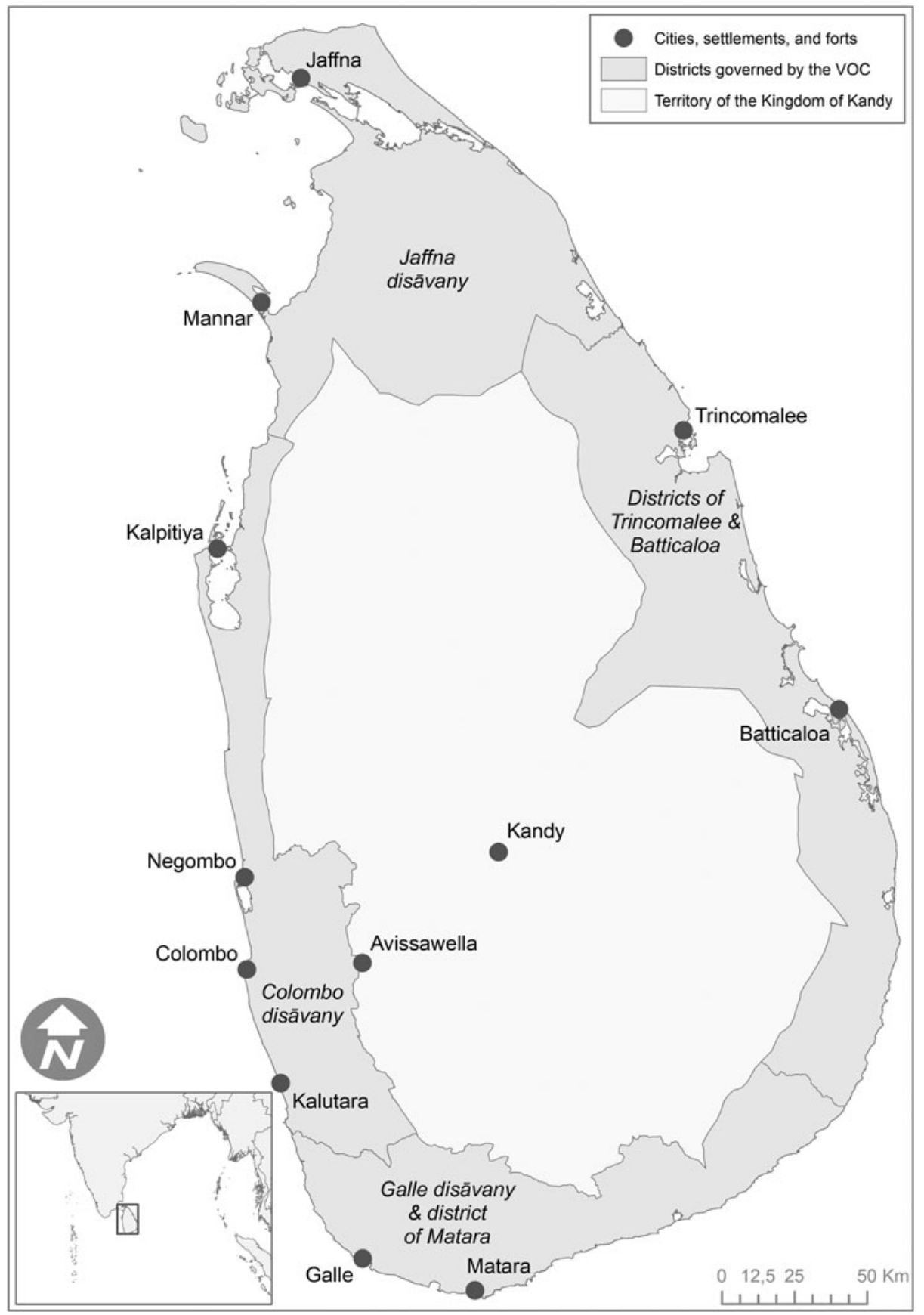

Figure 1. Map of Sri Lanka, 1766-1796, by (C Thijs Hermsen (Humanities Lab, Faculty of Arts, Radboud University). 


\section{A Divided Island? Identification and Classification under the Company's Rule}

Sri Lanka's geographic position, situated in the middle of the Indian Ocean on the "highway" between East and West and harbouring many natural resources, has determined its history. Throughout time the island has been frequented by different groups of traders, conquerors, migrants, and other travellers. Indian, Arabian, Chinese, and finally European influences have been a constant factor in the shaping of Sri Lanka's society and culture, which resulted in a melting pot, or arguably a salad bowl, of cultures, languages, religions, castes, and ethnicities. ${ }^{21}$ It was in this setting that the VOC in the early seventeenth century ventured to the island in search of its riches, most notably cinnamon, which had up until that point been monopolised by the Portuguese. ${ }^{22}$ After the Company had systematically conquered the Portuguese forts and outposts, "aiding" the local kingdom of Kandy in dealing with the common Iberian enemy, they established their own colonial government in the coastal regions of the island. Similar to the Portuguese system of rule on the island, the Dutch kept large elements of the local hierarchical structures intact. $^{23}$

At first, this system of indirect rule suited the Company's focus on cinnamon and other exotic products. With relatively little effort the Company could extract the precious commodities for trade on both the Asian and European markets. However, as the global markets changed and the colony in Sri Lanka started to become less and less profitable, the VOC's outlook on its management changed. To cover the loss of revenue, the colonial government in Sri Lanka from the early eighteenth century onwards started to shift its focus to taxation, land revenues, and plantation labour, which in turn resulted in an intensification of the VOC's political, territorial, and societal influence on the island. ${ }^{24}$ With this increase in interference in the political and societal sphere came a growing interaction with the local population and therefore a growing need for the Company to understand and control them. ${ }^{25}$

In his early work on urban spaces in VOC Asia, Raben emphasised the Dutch policy of "classify and rule," whereby attempts were made to divide subjects into clear, workable, and pragmatic categories. ${ }^{26}$ This paper reality, however, was an oversimplified, generalised, and limited representation of the true social structures found in places like Batavia and Colombo, and, according to Raben, a clear result stemming from the limited experience the colonial administrations in these cities had with the local population. ${ }^{27}$ As such we can expect to find the roughest ethnic-administrative categories in the reports produced by the higher compartments of the Dutch bureaucracy in Sri Lanka, for example in the missives. ${ }^{28}$ In a recent article, Raben revisits the centrality of the ethnic labels produced by VOC administration, and writes a call for arms to question social categorisations in colonial contexts. ${ }^{29}$ This article will pick up that gauntlet, and scrutinise the role of such ethnic labels in the southwestern coastal region of Dutch Sri Lanka. How did identification practices shape categorisation when the colonial administrators and local subjects met and interacted, for example in the process of the thombo registration or the judicial context? Would this diversify and complicate the classification of the 
people appearing before the VOC's bureaucratic apparatus? And can we actually distinguish between this apparatus on the one hand and the local population on the other, considering the large influx of translators, headmen, and native commissioners? Here we explore those bureaucratic spheres of reporting, registering, and litigating, and compare them with the identification practices of the people of eighteenth-century Sri Lanka.

\section{Reporting to the Motherland: Identification in the Missives of the Council of Ceylon}

In November 1766, a ship belonging to the VOC began the long and perilous journey from Colombo to Amsterdam. On board was the yearly missive sent by the Political Council of Ceylon, addressed to the highest board of the VOC in the motherland. This massive volume consisted of reports, lists, registers, correspondences, and many other documents detailing the governance of the Company's territories in Sri Lanka. The overarching theme in the reports was the economic situation concerning the VOC's commercial activities in the region. However, it also carried an account of the religious situation, which came under additional scrutiny after the war with the independent Kandyan kingdom in the island's centre. In the report, the Council wrote that there was a great need for additional preachers to convert the large number of "heathens" and Catholics to the Protestant faith. ${ }^{30}$ They determined that the lack of Protestants on the island was the direct result of a pressing shortage of Dutch Reformed preachers and schools. This was a sharp contrast to the high number of Catholic schools and priests active on the island, according to the Council. ${ }^{31}$ To further illustrate the severity of the situation, the Council complained that there was only one Protestant preacher who spoke the Sinhalese language active in the Sinhalese south, and only one Protestant preacher who spoke "Malabar" (Dutch corruption of Tamil) in the "Malabar" north of the island.

Not only does this appeal from the Council suggest that the Company's colonial government on Sri Lanka was committed to the religious cause in their territories, it also seems to indicate the Council actively divided the island's coastal regions into two rough categories: namely, the "Malabar" (Tamil) north and the Sinhalese south. One could wonder about the implications this had on identity formation, as it was communicated as such in political spheres as far away as possible from the social reality "down below." However, it was the paper reality the Political Council seems to have worked with, and thus the type of knowledge that was actively used in the making of political, commercial, diplomatic, judicial, and socioeconomic policy. How deeply was this "ethnic-administrative" division entrenched in the discourse of the Political Council then? Was it a division that stood at the basis of many of the Company's higher political courses of action? Or was this a one-off, which arose due to the pragmatic nature of governing an island harbouring people speaking multiple languages ? $^{32}$

From the fifty-nine (surviving) missives sent by the Political Council of Ceylon to Holland between 1766 and 1796, we have scrutinised the eight missives written around 
the time of the four changes of gubernatorial regimes. ${ }^{33}$ These missives showcase several different methods the Political Council applied in their classification of the island and its people. For the most part, the Council used local political or service-related terms to identify native inhabitants whenever the need arose. This was a pragmatic way to make a distinction between all the local people the Company had to deal with, especially considering their reliance on the system of indirect rule and local leaders. If there was no relevant political or service-related title available, the Company often relied on geographical denominations; for example, when someone came from the city of Galle he was mentioned to be a Gaalsche, or if someone came from Mannar, he was called a Manaarsche, and so on. However, next to these very practical indicators, the Political Council also clearly relied on a larger distinction between the Tamil-speaking north and the Sinhala-speaking south, especially when discussing matters concerning the entire island. This distinction often went beyond language alone, as we will argue below. Lastly, products, interestingly enough, were also connected to this rough distinction between the "people of the north" and the "people of the south," as with Tamil and Sinhalese cardamom.

One of the most striking examples of this ethnic-geographical division of the island by the Political Council can be found in a copy of the general description of the island's political and economic situation addressed to the Company's "High Government" in Batavia, which found its way to Zeeland along with a missive in $1788 .{ }^{34}$ It mentions that the colonial government under Governor Willem Jacob van de Graaff had adopted a resolution to reduce the number of kweekelingen (European children who were orphaned or whose parents were at sea) who were growing up in a "Sinhalese or Malabar's way of life." Beyond language learning, the Political Council's worry about these children was based on their belief that there was a Sinhalese or Malabar (Tamil) way of life, indicating a perceived cultural distinction between the Sinhalese and the Tamils. The same document mentions that an attempt to introduce paper money to the island had led to resistance amongst "the Sinhalese." The Political Council therefore decided to delay the plan, to prevent "the Sinhalese," who were responsible for all the provisions in the bazars (according to the report), from finding other ways to sell their "products from the land" (i.e., not through the markets controlled by the Company). ${ }^{35}$ More than just a reference to linguistics, with the "Sinhalese" the Council was referring to the behaviours and charateristics of a social group, one opposed to others inhabiting the island (such as, potentially, the Tamil-speaking communities).

In at least four of the eight missives we examined, the Political Council makes similar distinctions between the Sinhalese and the Tamils. This suggests that the Political Council had classified the island using rudimentary categories. ${ }^{36}$ In turn, this implies that the ethnic division of the island on an administrative scale took place much earlier than suggested in literature on the British period. ${ }^{37}$ As such it is entirely possible that the division of the island's population by the Company on the basis of the most obvious distinction for an outsider, namely language, could have had its influence on identity formation amongst Sri Lanka's society due to a "trickle-down effect" through VOC policy-a process with roots in the Portuguese period. ${ }^{38}$ 
Interestingly, this language-based division may have had to do with the Company's larger sphere of influence around the Indian Ocean, and as such may have had a bigger impact on local society in the sense of emphasising "otherness." 39 The VOC's presence and activities throughout the Indian Ocean world become very apparent when studying the missives sent from Sri Lanka to Holland and Zeeland. There are dozens of reports and inventories that showcase the Company's interconnected trade network amongst their different territories and factories around India and Sri Lanka. ${ }^{40}$ As such the Dutch, and the Portuguese before them, encountered and recognised the similarities in language and culture between the Indian south and Sri Lanka's northern regions. They also witnessed the continuous relations, migrations, and trade networks between the subcontinent and the island's "Malabar" population in the north, leading them to consider the southwestern regions of Sri Lanka as a Sinhalese area, and thereby framing Malabars and "Indian foreigners" as outsiders in those densely populated coastal areas.

It is thus very likely that the European officials of both the Iberian and Dutch empires were influenced in their categorisations by presumed cultural and lingual relations between some of the social groups they encountered throughout their territories and outposts in the Indian Ocean world. The fact that this actually influenced policy in Sri Lanka and as such had its impact on the daily lives of many local subjects points towards probable effects on identity formation processes regarding these societies. Additionally, this implies a top-down categorisation of the island's population based on a certain assumption of ethnicity well before the British period. We should not underestimate the existence of the cultural and linguistic differences between roughly the northern and southern populations, even though they were highlighted in a very crude fashion by colonial categorisation. However, even though the political power of the Political Council of Ceylon and the reach of their policies' implications should not be ignored, the possible impact of the simplifications in the missives on the everyday bureaucratic practices in Sri Lanka remains a question mark.

To explore the dynamics behind identification on the ground level, so to speak, we must venture farther into the paper jungle of colonial bureaucracies to spheres of registering and litigating, where the colonial apparatus interacted and communicated with subjects from every walk of life. To question how the so-called ethnic division functioned at the conjunction of the colonial and local spheres, if it did at all, and how it impacted local identities (and vice versa), we will compare our findings from the missives with research into the mid-eighteenth-century thombo registers and the civil cases brought before the Council of Justice in colonial Sri Lanka.

\section{Negotiated Categorisation? Registration of People and Services in the Thombos}

When the Portuguese arrived in Sri Lanka in the late sixteenth century, the island's communities already relied on an extensive system of registering people and their property. ${ }^{41}$ In the southern regions a complex land tenure system, not unlike the feudal system from 
medieval Europe, necessitated the documentation of the lands that were owned by the Sinhalese kings, those that were gifted to families and headmen, and those that were gifted to religious entities, such as temple grounds. The latter two were theoretically free from taxation or labour services, but the rest of the king's lands, whether cultivated by the commoners or in any other way utilised with the king's permission, were subjected to "a duty to the king" (räjakāriya). ${ }^{42}$ This was either fulfilled through taxation or through an unpaid labour service. To keep track of this division of land and labour, written records were kept by village scribes on palm leaves (olas), and collected in bundles called the lēkam miti. ${ }^{43}$

The Portuguese, after they took control of the kingdom of Kotte and conquered some of the neighbouring territories, were interested in replacing these rulers to become the lords of the lands (bhupati) themselves, so that they could claim the rājakâriya privileges. $^{44}$ To this end they implemented the tombo registries, known throughout the Iberian empire as a sort of cadastre, but in Sri Lanka heavily influenced by the lekkam miti. ${ }^{45}$ Upon conquering the Portuguese territories in the seventeenth century the VOC maintained this administrative tool, and Governor van Goens immediately ordered a revision in Dutch. However, by the end of the seventeenth century most efforts to create a Dutch thombo ${ }^{46}$ registry were discontinued (except for Jaffna and Galle). High costs, the accidental destruction of most Portuguese registers, and (most importantly) the VOC's focus on the production of cinnamon were the primary reasons for its demise. ${ }^{47}$

A few decades later, specifically by the 1740 s, cinnamon production had gone down and simultaneously cinnamon prices in Europe had decreased drastically. Additionally, the southwestern regions had witnessed a population growth and a parallel increase in agricultural activity. Consequently, the Company looked to make the Dutch territories in Sri Lanka profitable again by transforming from an export-oriented economy (e cinnamon, elephants, and other "exotic" products) towards revenues from agricultural productivity and domestic policies. ${ }^{48}$ A fundamental element of this conversion was an extensive bureaucratisation process, whose crowning achievement was the centralised reinstatement of the Dutch thombos in the southwestern Company territories in Sri Lanka.

By 1760, nearly the entire southwest coast of Sri Lanka had been described in these land and population registers. ${ }^{49}$ For the Colombo district, which will be the main focus of this segment, the thombos were divided into "head" and "land" thombos. The first contained demographic and genealogical data for all the families registered, and could be connected to the land thombos, which recorded the families' landed property and its contents in fruit-bearing trees and rice fields, accompanied by a concise "genealogy" of how these lands ended up in the families' hands. ${ }^{50}$ In the head thombos, a family's entry was marked by the head of the family, usually the highest-ranking male, who was registered by name, age, occupation/service, and a certain communal classification (as we shall see below, almost exclusively based on caste, or on another communal denominator, like religion). ${ }^{51}$ The other family members were then registered below the head, based on their genealogical relationship to the head, and also registered by name and age. Service and/ 


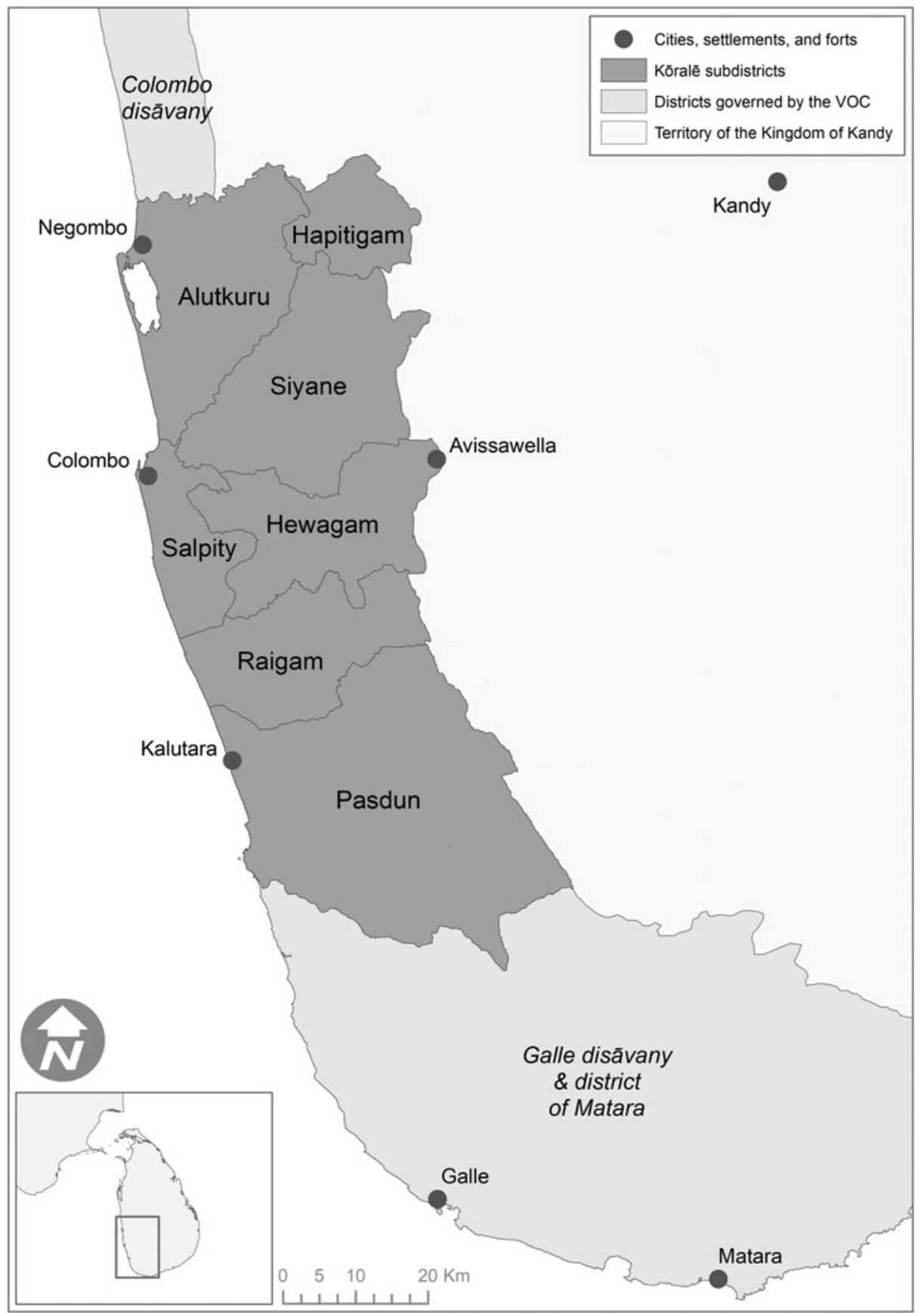

Figure 2. The kōralē subdistricts of the Colombo disāvany (or district), 1766-1796. 
Table 1. Caste-based and communal categories of landowners in the 1760-1770 thombos of the Siyane and Hapitigam subdistricts. ${ }^{54}$

\begin{tabular}{|c|c|c|c|}
\hline $\begin{array}{l}\text { Categorisation in } \\
\text { thombo }\end{array}$ & $\begin{array}{l}\text { Present-day caste/ } \\
\text { community }\end{array}$ & Description & $\mathrm{N}$ \\
\hline Bellale & Goygama & Landowners caste, agriculturists & 849 \\
\hline Padoewa & Padu & Agricultural caste, peasantry & 138 \\
\hline Jagereroe & Hakuru & $\begin{array}{l}\text { Caste of sugar burners, performed menial } \\
\text { services }\end{array}$ & 88 \\
\hline Wasser, Hinnawa & Radā, Hinnawa & $\begin{array}{l}\text { Castes associated with the ceremonial washing } \\
\text { of, and decorating objects with, linen }\end{array}$ & 54 \\
\hline Chiando & Durāva & Caste of toddy-tappers & 47 \\
\hline Visser & Karāva & Caste primarily associated with fishing & 36 \\
\hline Moor & Sri Lankan Moors & Muslim communities with South Indian roots & 9 \\
\hline Kalkbrander & Hunu & Caste of lime burners & 6 \\
\hline Priester & Priest & $\begin{array}{l}\text { (Probably) indigenous priests of the Dutch } \\
\text { Reformed religion }\end{array}$ & 5 \\
\hline Smid, timmerman & Āchāri & Caste of artisans, mostly blacksmiths & 5 \\
\hline Tamblinjero & Tamblinjero & Drummer, tom-tom beater & 5 \\
\hline Coelij & Coolie & Labourers & 4 \\
\hline Baardscheerder & Ämbättayo & Caste of barbers & 2 \\
\hline Chittij & Chetty/Chettiyar & $\begin{array}{l}\text { Tamil-speaking community found throughout } \\
\text { Indian Ocean world, primarily known as } \\
\text { merchants }\end{array}$ & 2 \\
\hline Pottenbakkers & Badähala & Artisan caste, mainly potters & 2 \\
\hline Other & & & 7 \\
\hline Total & & & 1259 \\
\hline
\end{tabular}

Source: Database of the Udugaha, Hapitigam and Meda, Siyane head and land thombos, based on SLNA 1/3772, 3856, 3776, 3860, 3861.

or communal classifications were omitted unless they deviated from those of the family head. ${ }^{52}$ To illustrate which categorisations were most common in the thombos, we have analysed the way the land owners found in the registers of two rural subdistricts within the Colombo province were labelled between 1760 and 1770 (see figure 2 for specific locations). ${ }^{53}$

Compared to the categorisations found in the missives, in the thombos the protoethnic divide based on a common lingual or cultural tradition (almost) completely disappears, further underlining the VOC's lack of an overarching system to consistently identify its subjects. ${ }^{55}$ Rather, as was suggested above, the categories in the thombos (as highlighted in table 1) were directly related to caste. Why the VOC maintained very different categories in the thombos compared to the missives is relatively obvious. Firstly, the thombos were more localised and thus allowed for much more precise and diverse labelling. Secondly, and more importantly, these registers were established to enable the enforcement of caste- and community-based labour duties and taxation in favour of the Company. 
Most services were exclusively related to certain communal or caste groups. ${ }^{56}$ For example, those communities that were considered "foreign" (or "outlandish") ${ }^{57}$ had to perform the uliyam service in exchange for permission to reside in the Dutch territories. ${ }^{58}$ Similarly, those who belonged to specific Sinhalese caste communities often had to perform certain services both for the Company and within the local social hierarchy, often organised on the village level. Additionally, many such services were paired with plots of land that the service-providing agents received as compensation for their (caste-based) duties, thus requiring meticulous record-keeping. These services were diverse and ranged from menial labour - often performed by the "lower castes," such as the washers $(\operatorname{rad} \bar{a})$ and sugar burners (hakuru) — to more administrative and even political and military roles, which were often reserved for the higher castes, such as the goygama (registered by the Dutch as bellale, a corruption of the Tamil word vellalar, which also describes a caste of landowners).

The registration of these categories, and the subsequent services "belonging" to these categories, were obviously driven by colonial interests in the service obligations related to each social category. Additionally, these categories are the result of the colonisers' perception of the highly complex social structures of the many different communities then living in Sri Lanka. Looking at the thombos, it becomes clear that the quest for legibility, and the subsequent ability to enforce the communities' alleged duties to the Company (through their claiming to be the bhupati) influenced the social classification system that was maintained in these thombos. In other words, the Company's ideology determined the system of classification presented in the thombos.

However, it would also be incorrect to merely dismiss these categories as colonial social constructs produced through a set of foreign eyes. The history of (the thombo) registration in Sri Lanka is littered with signs of local influence and agency. ${ }^{59}$ For one there is the influence of local, precolonial structures, such as the lékam miti and the räjakāriya system in general. ${ }^{60}$ Even more profound is the extensive reliance on local infrastructures, categories, and intermediaries, and their subsequent influence on the thombo registration process. Specifically, the thombo registration process was largely carried out by local scribes, surveyors, and commissioners. Additionally, local people were expected to come to the thombo scribes when the latter visited their lands, and even though they were hesitant and anxious at first, over the years the local populations became more and more experienced in navigating these administrative structures and started to see the advantage of having themselves and (more importantly) their property registered and thus recognised. ${ }^{61}$ Additionally, numerous cases are known where local agents negotiated with Company officials about what was registered in the thombos, and even had what was registered altered, for example through court cases or through having more land ascribed to their names with the promise of extra labour or service duties as compensation. ${ }^{62}$

Taking the dynamic nature of the thombos into account, the social categories and structures found in the registers indicate that we should not only consider identities to be fluid, but categories as well. They may seem fixed, but the type of document and its affordance to both those registering and those registered determines what 
categories are used and how they are shaped. The question thus arises of to what extent this phenomenon played out in the sphere of Dutch bureaucracy that probably best captured cultural practices, social norms, and interactions, namely the civil law courts. ${ }^{63}$ Additionally, legal documents produced by colonial or imperial administrations are among the few sources left by such bureaucracies that allow us to find traces of the local voices. ${ }^{64}$

\section{Before the Dutch Court: Identification in Council of Justice Civil Case Documents}

Throughout the Asian frontier of the Dutch empire, the VOC was authorised by the Dutch Republic to autonomously wage wars, handle diplomatic relations, and govern the territories overseas, the latter including jurisdiction and law. The Company had a central government in Batavia from which statutes and policies were sent, but throughout the Company's dominions there was a vast diversity in how these lands were governed and what laws prevailed. Dutch Sri Lanka was exceptional in the sense of the vastness of the lands actually governed by the Company, and because of the relatively early creation of colonial institutions like the courts. By the seventeenth century a relatively complex judicial system was already created and maintained by the Dutch and their local commissioners, mainly due to the frequency of the disputes with the indigenous kingdom of Kandy on land and trade rights. ${ }^{65}$

By the 1740s the judicial system had manifested in a structure where the three largest cities under Dutch control-Colombo, Galle, and Jaffna-had their own Council of Justice, of which the one in Colombo was the highest. Then every Council of Justice had a subordinate Civil Council for petty civil cases and a Rural Council for matters in the hinterlands. The Councils of Justice took upon them all the matters concerning employees of the Company and every criminal case, as well as every civil case that was deemed severe in nature or with large financial consequences. Additionally, appeal cases were held before the Councils of Justice. ${ }^{66}$

Figure by the author, based on Schrikker (2007, 2015) and Rupesinghe (2016).

For this study we opted for the Council of Justice in Colombo, as its status as highest appellate court of the island ensured a higher degree of geographical distribution and thematic diversity compared to the two other Councils of Justice (see figure 3). Local people from all over the island participated in identification processes here through their witness accounts, letters, reactions, and interrogations. ${ }^{67}$ More than in criminal suits, civil cases where two opposing parties challenge each other before a "neutral" Dutch court offer us evidence on bottom-up identification practices. ${ }^{68}$ The civil cases handled by the Council of Justice in Colombo (or simply the Council from here on) thus allow us to adopt a new perspective on the way officials of the Company identified and categorised the local inhabitants appearing before their institution, and how the litigants might have influenced this process themselves.

The 203 preserved civil case files of the Dutch Council of Justice range from 1732 to 1796. ${ }^{69}$ While these files held the testimonies, transcribed interrogations of witnesses, 


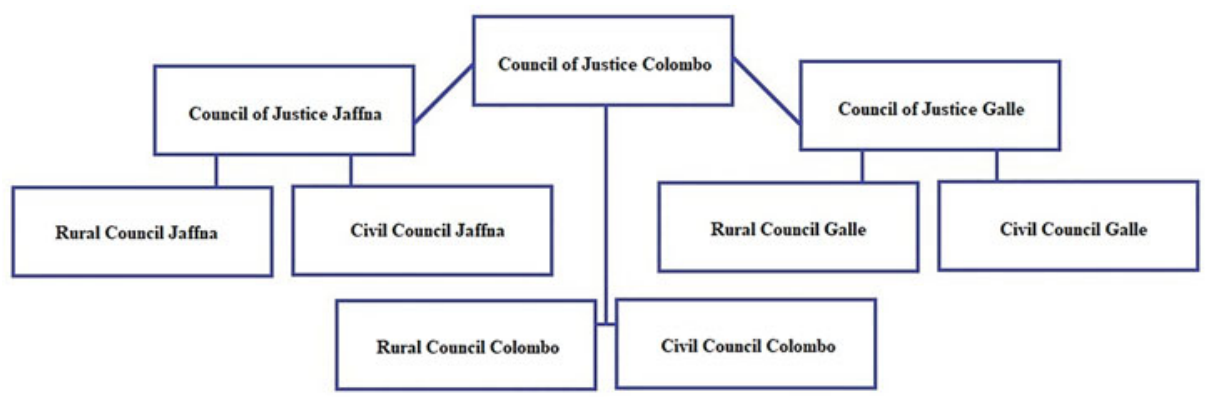

Figure 3. Schematic overview of judicial structure on eighteenth-century Dutch colonial Sri Lanka.

and (translated) pieces of evidence pertaining to the case, the core document was the collected extracts from the civil rolls. The Council held weekly meetings where they dealt with both new cases and followed up on existing ones, which were all chronologically noted down in the rolls. A general overview of these rolls for the 203 files does not immediately reveal a systematic approach to the identification of the people appearing before the court. Professions were an important element in identifying litigants, certainly if one was directly employed by the Dutch East India Company (sailors, soldiers, merchants, accountants, etc.). Along the same vein, indigenous individuals with colonial functions were primarily identified by those titles (e.g., mudaliyārs, ārachchi, and $k \bar{o}$ rale , all political/military titles that were of high importance in the Dutch system of indirect rule). Interestingly, the most common classification used in the studied documents is a notion of ancestry. ${ }^{70}$ Even more remarkable is the fact that a certain ethno-communal category, rather than caste, seems to have been the main nominator, while literature suggests caste was a far more important identifier in the pre-British period. ${ }^{71}$ A handful of cases mention a litigant from the "bellale" caste, which was a Dutch corruption of both the Tamil vellalar and the Sinhalese goygama castes of landowners (as was mentioned above), while several others mention the madapallie caste, the first caste-group below the vellalar caste. There is no apparent reason that the Council of Justice opted to identify the litigants in those cases by caste. The cases involved all sorts of situations, including debt, land ownership, inheritance, and one case between a mistress and her enslaved servant. Are we missing a conscious decision here? Or was it influenced by the litigants themselves?

Contrary to categorisation based on caste, the Dutch documents reveal a dominant ethnic categorisation of the litigants as Burger, Moor, ${ }^{72}$ Sinhalese, and Chetty. ${ }^{73}$. While the appearance of the first three ethnic categories was to be expected from the historical literature on Dutch Sri Lanka, the relatively high number of Chetties raises questions. ${ }^{74}$ In the limited literature available on the Sri Lankan Chetties, they are identified as a group of Tamil-speaking merchants, bankers, and creditors, originally from South India and/or from families with extensive trade networks in India and the Indian Ocean world. ${ }^{75}$ Supposedly this was a relatively small group of economically and politically 
Table 2. Ethnic categorisations in Council of Justice court records.

\begin{tabular}{llll}
\hline \hline & Plaintiffs & Defendants & Total \\
\hline Burger & 9 & 11 & 20 \\
Moors & 10 & 9 & 19 \\
Sinhalese & 29 & 13 & 42 \\
Chetty & 24 & 29 & 53 \\
Total & $\mathbf{7 2}$ & $\mathbf{6 2}$ & $\mathbf{1 3 4}$ \\
\hline \hline
\end{tabular}

Source: Court records, Council of Justice, 1732-1796

active families in the coastal areas of Sri Lanka, mainly in the southwest. The fact that they were often engaged in financial activities involving bonds, loans, estates, and investments, plus the idea that this group of families was relatively wealthy, could explain their high number of appearances in the studied civil cases. However, the potential "colonial mix-up" of the Hinduist, Tamil-speaking inhabitants of (northern) Sri Lanka and their fellow Dravidian-language-speaking and majority Hindu groups of South India could also play a role here. In addition, it was not unusual that Tamil-speaking litigants and witnesses from southern India appeared before the Council of Justice in Colombo, further pointing to the interconnectedness between distant territories in South Asia. ${ }^{76}$

At first sight the Chetties seem to be identified by the Company as a distinct group based on a sort of ethnic stratification. However, the Company and/or the Chetty litigants themselves saw a sharp dichotomy, distinguishing between the "Christian" and the "heathen" Chetties. ${ }^{77}$ Raben states there was a group of Christian Chetties (in our cases mostly Roman Catholics ${ }^{78}$ ) who had lived in Sri Lanka for a longer period of time and considered themselves to be the "true Chetties," in comparison to the relatively recent "heathenly" (Hinduist) migrants from South India. ${ }^{80}$

What the VOC thus considered to be Chetties were an incredibly diverse group. One key element binding this heterogeneous group together is their common South Indian descent, and with it their shared preference for the Dravidian speech, particularly Tamil. A majority of the cases involving one or multiple "Chetties" were supplemented with all sorts of documents, (translations of) bonds, olas (written texts on palm leaves), testimonies, letters, and so on, and often guided by Tamil-speaking interpreters. ${ }^{81}$ In one particular case this connection between the Chetties and the Tamil language got an interesting twist when the Chetties involved in that dispute were attributed certain "typically Malabar" conventions concerning dowry gifts, and one lady - the mother of the defendant—had allegedly been called a "dim-witted, dumb Malabar woman." 82

Interestingly, no "Malabars" have been identified as such in the court cases examined in this study and the only references to Malabar or Tamil were considering language. But in this specific case we see two incidents where this term seems to transcend the notion of language alone, in a case where the parties concerned were identified as Chetties by the court. Could this imply that the Company indiscriminately categorised Tamil-speaking 
people under the nominator of Chetty? In one of the population registers (head thombo) of 1767, only sixteen Tamil families were not registered as "Chetties," while most others were categorised as such. ${ }^{83}$ Therefore, similar to our findings in the missives, it is plausible that many Tamil-speaking Sri Lankans in the eighteenth century had connections with trade networks and/or family relations in India. This, combined with European ignorance in considering all Tamil-speaking people to be "foreigners" in Sri Lanka, caused the category of "Chetty" to become a common way to identify Tamil-speaking people in the southwestern part of the island, even in the lower levels of colonial administration, which were more in touch with the local society. From the point of view of Company officials, this is not such a far-fetched idea. Multiple trials taking place at the Council suggested a high level of interconnectivity amongst so-called Chetties all across the Indian Ocean world. ${ }^{84}$

These cases illustrate the complexity and connectivity of the Indian Ocean world in that time ${ }^{85}$ In that sense it is thus imaginable that Company officials and other European colonials, who had the most contact with "connected" individuals like merchants, traders, and headmen, came to use such categories. However, this highlights one of the problems with such a conclusion based on this particular set of sources. For one thing, the reason the Chetties were over-represented in court records may well have to do with their being the most visible group in the civil cases at the highest judicial court, because they had the wealth to produce cases that were considered worthwhile by the officials of the Council. Additionally, this hypothesis fails to truly take into account local agency and influence on the identification process. We have seen some signs of selfidentification within the group, for example in some written statements of litigants or witness reports, but this says next to nothing about the actual reality behind the potential local influence on identification.

A final example brings us back to the relational concept of identity formation utilised by Brubaker and Cooper, and could provide a last promising perspective on the matter. In a civil case about the ownership of a piece of land dated to the summer of 1740, two Sinhalese men named Fernando Domingo and Don Francisco brought their problem before the Dutch Council of Justice. ${ }^{86}$ As usual, plaintiffs and defendants called on witnesses to testify on their behalf, supporting their version of the story. In this case Fernando Domingo called upon two men, first referred to as "Louis Cangaan and Francisco Nainde, both Sinhalese from outside of Colombo." These men went through the process of being formally admitted to testify, actually being interrogated, followed by a counter-interrogation by the defendant, and finally summoned back to court to validate their testimonies. Interestingly enough for this paper, these two men were identified differently every time they came into contact with the Council members or the clerk. In the time span of only twelve days dealing with the same institution, they were mentioned in the court file as:

Louis Cangaan and Francisco Nainde, ${ }^{87}$ both Sinhalese from out of town [Colombo]; Louis Nainde bellale and Francisco de Silva fisherman, both Christians and inhabitants of Colpittij [Kollupitiya] out of town [Colombo];

Louis Nainde bellale and Francisco de Silva fisherman; 
Louis Nainde bellale and Francisco de Zilva fisherman, both inhabitants of Colpittij [Kollupitiya].

This image makes it even harder to try to reconstruct the motivations behind (self-) identification. Multiple signifiers seem to have been used indiscriminately here, with names, caste positions, caste, ethnicity, religion, and residence employed as building blocks to identify the witnesses at hand. Although there was certainly no systematic identification, there seems to have been a process of zooming in, moving away from the general identifiers as Sinhalese living outside of Colombo to more specific caste denominations and an actual geographic location. This case study raises more questions than it can answer; for example, what was the precise role of the witnesses themselves in the written identification? Were these literal transcripts of spoken self-identifications, or a redacted version by the clerk? Was the evolution from a more general to a more specific categorisation a natural one, or steered by either the Council or the witnesses? Is it plausible to assume that we see an example at work of identity crafting through negotiation, whereby denominations applied to individuals by an institution were absorbed by them and re-articulated when they reappeared before that same institution? And if so, to what extent did these partly appropriated identity markers influence future encounters with other segments of Dutch colonial bureaucracy and registration?

The civil cases attended to by the Council of Justice of Colombo give us glimpses of the complicated and multilayered society in which the legal institutions of the VOC in Sri Lanka had to navigate in their attempts to "do justice." ${ }^{, 88}$ Still, the simplistic classification of Sinhalese-speaking and Tamil-speaking populations on the island was not shunned in the Council's attempt to classify and identify the people appearing before their court.

So it seems the stereotypical division of the island's society was not limited to the discourse of the Political Council in their missives, but also appeared in the litigating sphere of the Council of Justice. Both sources do showcase quite convincingly that this distinction was not only important for the Dutch administration, but also transcended a mere linguistic division. In both the missives and in the civil cases we see indications of certain characteristics, actions, and problems that are attributed to the group-identities of the Sinhalese-speaking or the Tamil-speaking communities. Much more apparent in the Council of Justice cases in comparison to the missives of the Political Council is the deep social complexity and the cultural connectedness of Sri Lanka's society and its place in the Indian Ocean world. This complexity, and in particular the way the Council of Justice handled it, is most obvious in the cases surrounding caste-based identification.

All in all we have been unable to discern a clear pattern in the Council of Justice's identification practices. Despite this, a considerable number of cases consisted of a certain ethnic-administrative category, which in practice came down to either the Chetty or the Sinhalese denotation. Together with our findings in the missives of the Political Council, it seems that the scant literature on ethnic identification by the VOC in eighteenth-century Sri Lanka was correct to deduce that the Company generally categorised Sri Lanka's complex society in a simplistic and stereotypical fashion. ${ }^{89}$ This 
particularly seems have come down to a rough divide between the Sinhalese- and Tamil-speaking communities, but ascribed characteristics seem to have outclassed linguistic differences on their own. At the same time it is clear that the Company had to deal with a complex and dynamic society defined by its many different historical communities, castes, cultures, languages, peoples, and ethnicities, and the Company's officials were struggling to find their way to impose order onto the perceived chaos. Additionally, we see signs of local agency in the way individuals were categorised by the judicial courts and the registrars, apparently negotiating their own identity labels through their witness statements, interrogations, letters, and other legal documents. Thus a much more complicated social system appears in the paper reality left by the VOC's offices closer to the actual communities they described.

\section{Concluding Remarks}

Building on earlier historiography on identity formation in Sri Lankan history, this article questions the British period as prime mover in these debates. In order to do so, we leaf through the paper realities of reporting, registering, and litigating by eighteenth-century Dutch bureaucracies in the coastal regions of the island, specifically the southwest. We discover that the rough ethno-communal division of the Sinhalese and Tamil (in Dutch corrupted to "Mallabar") imagined communities predated the modern era of Sri Lanka, further underlining the long, dynamic, and complex history of contemporary ethnic identities. Ethnical stereotypes related to language and culture appeared most prominently in the political discourse found in the correspondence between the Political Council of Ceylon in Colombo and the Company officials in Holland. These blunt categorisations also made it into everyday judicial administration, and to a lesser extent the thombo registration of land, people, and services, contrary to what has been assumed in earlier literature. ${ }^{90}$

At the same time, these paper realities make it clear that there was no uniform ideology that steered Dutch categorisation practices top-down throughout colonial institutions. Identification practices were highly situational, dependent on the interests of both the colonial officials and the subjects. Especially in those segments of bureaucracy where officials interacted more closely with local communities, Dutch paperwork showcases more detailed sensitivities to social categories. The rationale of the institution in turn affected the way people were classified, determined to a large extent by what level of bureaucracy people were dealing with, and what the possible negotiation was for the people recorded. In the thombo registers related to land matters, caste, service, and to a lesser extent religion were the more crucial denominators, while litigation practices mainly added ethnic-administrative labels to that list, and put more emphasis on religious background. Unlike the missives, but very similar to the judicial records, the categories in the thombos were not just top-down, "orientalist" descriptions of the colonised by the colonisers; rather, they were influenced by local infrastructures, agents, and situations. ${ }^{91}$ As such we should not just utilise or only deconstruct the categories and social structures 
as they appear in such sources, but strive to understand the process by which they were created, and see how the different rationale behind those archives determined categories. $^{92}$

References to Moorish landowners, creolised Burghers, and Chetty litigants in Dutch bureaucracies demonstrate the continuing importance of studying community formation outside of the "traditional" social groups of localised Sinhalese and Tamils as well. In addition, their recorded presence testifies to the dynamic society of eighteenth-century Sri Lanka and its place in the wider Indian Ocean world through migration, trade, and travelling merchants and colonial officials. Although colonial institutions in Dutch Asia as such were highly localised and adapted to specific circumstances, they were also part of a web of legality woven across the Indian Ocean world, urging us to move beyond hyperlocalised studies on (Dutch) South and Southeast Asia. ${ }^{93}$ Future research should certainly take this interconnectedness of institutions, ideologies, and individuals into more account, to understand its role on practices of identification and classification in Sri Lanka and beyond. ${ }^{94}$ We should see the identification and classification process as a dynamic, dialectic, and cumulative enterprise in the long term. Questions should perhaps not be asked about when certain ethnicities were "made up," but rather about the institutional contexts in which they were recorded and how changing bureaucratic practices not only articulated but also transformed them in the long run.

\section{Aknowledgements}

This article was written in the context of the NWO-funded project Colonialism Inside Out: Everyday Experience and Plural Practice in Dutch Institutions in Sri Lanka, 1700-1800, which was carried out in cooperation between Leiden University, Radboud University Nijmegen, and the Sri Lankan National Archives. The authors would like to thank the commentators and participants of the conference Colonial Institutions and Uses of Law (Nijmegen, January 2019) and the AISLS Workshop (Colombo, August 2019), as well as Alicia Schrikker and the anonymous referees for their insightful comments on earlier drafts of this article.

\section{Bibliography}

\section{Unpublished Primary Sources}

Nationaal Archief (NA), The Hague, VOC-archive 1.04.02

-9944-45, 9946, 9994-95, 9996, 10029, 10048, Missives sent by the governors and the Political Councils of Ceylon to the Heren XVII, 1764-1795;

-10012. Missive sent by the governor and the Political Council of Ceylon to the Heren XVII, containing a general description of Ceylon compiled for the governor-general and the councils of the VOC, 31 January 1788.

Sri Lankan National Archive (SLNA), Colombo, Dutch Records Lot 1

-2466 . Drafts and translations of instructions issued by the governor to native headmen. 4 January 1745-1767; 
-3670. Translations of reports by commissioners on the lands and gardens cultivated in the Salpiti korale, with notes as to how far they have been entered in the tombo. Compiled at Hulftsdorp. 1770 June 20 and August 8;

-3739. Head thombo series 1766.71, Siyane kōrāla, Meda pattu;

-3758. Head thombo series 1766.71, Colombo Four Gravets;

-4194-4547. "Documents in civil cases."

Database of the Udugaha, Hapitigam and Meda, Siyane head and land thombos, based on SLNA 1/ $3772,3856,3776,3860,3861$.

\section{Secondary Sources}

Abhayawardhana, H. A. P. Lēkam Miti Vimarshanaya (A Critical Study of Lekam Miti). Colombo: Department of National Archives, 2009.

Anderson, Clare. Subaltern Lives: Biographies of Colonialism in the Indian Ocean World, 17901920. Cambridge: Cambridge University Press, 2012.

Bayly, Christopher A. "The Pre-history of 'Communalism'? Religious Conflict in India, 17001860." Modern Asian Studies 19:2 (1985): 177-203.

Bayly, Susan. Caste, Society and Politics in India from the Eighteenth Century to the Modern Age. Cambridge: Cambridge University Press, 1999.

Benton, Lauren. Law and Colonial Cultures: Legal Regimes in World History, 1400-1900. Cambridge: Cambridge University Press, 2002.

Biedermann, Zoltán, and Alan Strathern. Sri Lanka at the Crossroads of History. London: UCL Press, 2017. http://www.ucl.ac.uk/ucl-press/browse-books/sri-lanka-at-the-crossroads-of-history.

Breckenridge, Keith, and Simon Szreter, eds. Registration and Recognition: Documenting the Person in World History. Oxford: Oxford University Press, 2012.

Brubaker, Rogers, and Frederick Cooper. Colonialism in Question: Theory, Knowledge, History. Berkely: University of California Press, 2005.

Bulten, Luc, Jan Kok, Dries Lyna, and Nadeera Rupesinghe. "Contested Conjugality? Sinhalese Marriage Practices in Eighteenth-Century Dutch Colonial Sri Lanka." Annales de Démographie Historique 135:1 (2018): 51-80.

Bulten, Luc. "Reconsidering Colonial Registration: Documenting People, Property, and Labour in Eighteenth-Century Sri Lanka." Forthcoming PhD diss., Radboud University Nijmegen, expected 2022.

De Silva, K. M. A History of Sri Lanka. London: C. Hurst \& Company, 1981.

Dewasiri, Nirmal Ranjith. The Adaptable Peasant: Agrarian Society in Western Sri Lanka under Dutch Rule, 1740-1800. TANAP Monographs on the History of Asian-European Interaction, vol. 9. Leiden: Brill, 2008.

— . "'History' after the War: Historical Consciousness in the Collective Sinhala-Buddhist Psyche in Post-War Sri Lanka." ICES Research Papers 9 (July 2013): 1-22.

Dharmadasa, K. N. O. "The Sinhala Buddhist Identity and the Nayakkar Dynasty in the Politics of the Kandyan Kingdom." In Collective Identities, Nationalisms and Protest in Modern Sri Lanka, ed. Michael Roberts, 99-128. Colombo: Marga Institute, 1979.

Ginzburg, Carlo. The Cheese and the Worms: The Cosmos of a Sixteenth-Century Miller. Baltimore: Johns Hopkins University Press, 1980.

Guha, Sumit. Beyond Caste: Identity and Power in South Asia, Past and Present. Leiden: Brill, 2013.

Gunawardana, R. A. L. H. "The People of the Lion: The Sinhala Identity and Ideology in History and Historiography." In Sri Lanka: History and the Roots of Conflict, ed. Jonathan Spencer, 45-86. Abingdon: Taylor \& Francis, 1990.

Jayasuriya, Shihan de Silva. "Trading on a Thalassic Network: African Migrations across the Indian Ocean.” International Social Science Journal 58/188 (2006): 215-25. 
Lyna, Dries. "Ceylonese Arcadia? Colonial Encounters in Mid-Eighteenth-Century Dutch Sri Lanka," in Building Bridges: Scholars, History and Historical Demography, ed. Paul Puschmann and Tim Riswick, 157-72. Nijmegen: Valkhof Pers, 2018.

McGilvray, Dennis B. "Arabs, Moors and Muslims: Sri Lankan Muslim Ethnicity in Regional Perspective." Contributions to Indian Sociology 32:2 (1998): 433-83.

Meyer, Eric. "Des Usages de l'histoire et de La Linguistique Dans Le Débat Sur Les Identités à Sri Lanka." Purusartha 22 (n.d.): 91-123.

Mottau, S. W. "Documents on Ceylon History (2): Documents Relating to the Tombo Registration of the Dutch Administration in Ceylon: Instructions Issued to the Tombo Commissioners." Ceylon Historical Journal 3:2 (1953).

O'Hanlon, Rosalind. "Colonialism and Social Identities in Flux: Class, Caste and Religious Community." In India and the British Empire, ed. Douglas M. Peers and Nandini Gooptu, 100-34. Oxford: Oxford University Press, 2012.

Paranavitana, K. D. Land for Money: Dutch Land Registration in Sri Lanka. Colombo, 2001.

Peebles, Patrick. "Colonization and Ethnic Conflict in the Dry Zone of Sri Lanka." Journal of Asian Studies 49:1 (1990): 30-55.

Pieris, Ralph. Sinhalese Social Organization: The Kandyan Period. Colombo: Ceylon University Press Board, 1956.

Raben, Remco. "Batavia and Colombo: The Ethnic and Spatial Order of Two Colonial Cities 1600-1800." PhD diss, Leiden University, 1996.

—. "Ethnic Disorder in VOC Asia: A Plea for Eccentric Reading." BMGN-Low Countries Historical Review 134/2 (2019): 115-28.

Ricci, Ronit. Banishment and Belonging: Exile and Diaspora in Sarandib, Lanka and Ceylon. Cambridge: Cambridge University Press, 2019.

Roberts, Michael. Sinhala Consciousness in the Kandyan Period 1590s to 1815. Colombo: Vijitha Yapa Publications, 2004.

Rogers, John D. "Early British Rule and Social Classification in Lanka." Modern Asian Studies 38:3 (2004): 625-47.

_Post-Orientalism and the Interpretation of Premodern and Modern Political Identities: The Case of Sri Lanka." Journal of Asian Studies 53:1 (1994): 10.

Rupesinghe, Nadeera. "Do You Know the Ninth Commandment? Tensions of the Oath in Dutch Colonial Sri Lanka." Comparative Legal History 7:1 (2019): 37-66. https://doi.org/10.1080/ 2049677X.2019.1613308.

_. "Navigating Pluralities Reluctantly: The Marriage Contract in Dutch Galle." Itinerario 42:2 (2018): 220-37.

- "Negotiating Custom: Colonial Lawmaking in the Galle Landraad." PhD diss., Universiteit Leiden, 2016.

Schrikker, Alicia. "Conflict Resolution, Social Control and Law-Making in Eighteenth Century Dutch Sri Lanka." In Exploring the Dutch Empire: Agents, Networks and Institutions, 16002000, ed. Catia Antunes and Jos Gommans, 227-40. London: Bloomsbury Publishing, 2015.

- Dutch and British Colonial Intervention in Sri Lanka, 1780-1815: Expansion and Reform. Leiden: Brill, 2007.

Schrikker, Alicia, and Kate Ekama. "Through the Lens of Slavery: Dutch Sri Lanka in the Eighteenth Century." In Sri Lanka at the Crossroads of History, ed. Alan Strathern and Zoltán Biedermann, 178-93. London: UCL Press, 2017.

—. and Dries Lyna, "Threads of the Legal Web: Dutch Law and Everyday Colonialism in Eighteenth-Century Asia," in The Uses of Justice in Global Perspective, 1600-1900, ed. Griet Vermeesch, Manon van der Heijden, and Jaco Zuijderduijn, 42-56. London: Routledge, 2019. - and Nira Wickramasinghe, eds. Being a Slave: Histories and Legacies of European Slavery in the Indian Ocean. Leiden: Leiden University Press, 2020. 
Serrão, José Vicente. "The Portuguese Land Policies in Ceylon: On the Possibilities and Limits of a Process of Territorial Occupation." In Property Rights, Land and Territory in the European Overseas Empires, ed. José Vicente Serrão, Bárbara Direito, Eugénia Rodrigues, and Susana Münch Miranda, 183-96. Lisbon: CEHC, 2014.

Silva, Chandra Richard de. "The First Portuguese Revenue Register of the Kingdom of Kotte." Ceylon Journal of Historical and Social Studies 5 (1975): 69-153.

Sivasundaram, Sujit. "Ethnicity, Indigeneity, and Migration in the Advent of British Rule to Sri Lanka." American Historical Review 115:2 (2016): 428-52.

- Islanded: Britain, Sri Lanka, and the Bounds of an Indian Ocean Colony. Chicago: University of Chicago Press, 2013.

Spencer, Jonathan. Sri Lankan History and the Roots of Conflict. Abingdon: Taylor \& Francis, 1990.

Strathern, Alan. "Controversies in Sri Lankan History." History Compass 2:94 (2004): 1-5.

_. "Treachery and Ethnicity in Portuguese Representations of Sri Lanka." In Engaging Colonial Knowledge: Reading European Archives in World History, ed. Ricardo Roque and Kim Wagner, 217-34. London: Malgrave, 2012.

Szreter, Simon, Hania Sholkanmy, and A. Dharmalingam. Categories and Contexts: Anthropological and Historical Studies in Critical Demography. Oxford: Oxford University Press, 2004.

Talbot, Cynthia. "Inscribing the Other, Inscribing the Self: Hindu-Muslim Identities in Pre-Colonial India." Comparative Studies in Society and History 37:4 (1995): 692.

van den Belt, Albert, Jan Kok, and Kees Mandemakers. "Digital Thombos: A New Source for 18th Century Sri Lankan Family History. Research Note." History of the Family 16:4 (2011): 481-9. Wagenaar, Lodewijk. Galle: VOC-vestiging in Ceylon. Amsterdam: De Bataafsche Leeuw, 1994. Washbrook, David. "South India 1770-1840: The Colonial Transition." Modern Asian Studies 38:3 (2004): 479-516.

Wickramasinghe, Nira. Slave in a Palanquin: Colonial Servitude and Resistance in Sri Lanka. New York: Columbia University Press, 2020.

—. Sri Lanka in the Modern Age: A History. New York: Oxford University Press, 2015.

Wickramasinghe, Nira, and Alicia Schrikker. "The Ambivalence of Freedom: Slaves in Jaffna, Sri Lanka, in the Eighteenth and Nineteenth Centuries." Journal of Asian Studies 78:3 (2019): 497-519.

\section{Notes}

* Dries Lyna is Assistant Professor in History at the Radboud University Nijmegen. He devotes his research time to studying everyday life in (sub)urban Dutch Sri Lanka, dealing with themes such as creolisation, categorisation, and bureaucratisation. In addition, he is leading a collaborative project with the University of Glasgow on slavery, forced migration, and family history in the Global South, 1700-1900.

- Luc Bulten is a PhD candidate at the same university, where he is wrapping up his manuscript on the registration of people, land, and services in eighteenth-century Sri Lanka.
1 Wickramasinghe, Sri Lanka in the Modern Age, 7-8; Sivasundaram, "Ethnicity, Indigeneity, and Migration," 429. See also Spencer, Sri Lankan History and the Roots of Conflict; Peebles, "Colonization and Ethnic Conflict"; Dewasiri, "'History' after the War."

2 Most famously, the debate between Sri Lankan historians R. A. L. H. Gunawardana and K. N. O. Dharmadasa regarding the supposed exact moment in history the Sinhalese identity emerged: see Gunawardana, "The People of the Lion," 45-86; and Dharmadasa, "The Sinhala Buddhist Identity." 
3 See in particular Meyer, "Des Usages de l'histoire," for an elaborate oversight of these debates, next to Wickramasinghe, Sri Lanka in the Modern Age, xiv.

4 See for example Gunawardana and Dharmadasa.

5 Best described by Sujit Sivasundaram in "Ethnicity, Indigeneity, and Migration," 429-31. See also Strathern, "Treachery and Ethnicity," 218-9.

6 For the latter wave of scholars, see in particular Rogers, "Post-Orientalism." An exception worthy of mention here is a 1996 dissertation by Remco Raben, in which he compares the socio-ethnic makeup of early modern Colombo to Batavia (Jakarta) - both being Asian cities governed by the VOC. Raben, "Batavia and Colombo."

7 The debate was obviously strongly influenced by similar debates on the effect of colonial categorisation on identity formation, specifically in India and the debate over whether caste was a primordial feature of Indian society or a colonial introduction; for more on that debate see, e.g., Bayly, Caste, Society and Politics; Guha, Beyond Caste.

8 Particularly noted by Strathern, "Controversies in Sri Lankan History," 1-5; Strathern, "Treachery and Ethnicity"; Biedermann and Strathern, Sri Lanka at the Crossroads of History.

9 Wickramasinghe, Sri Lanka in the Modern Age, xiv; Sivasundaram, Islanded; Sivasundaram, "Ethnicity, Indigeneity, and Migration."

10 Schrikker, Dutch and British Colonial Intervention, 211-15; Strathern, "Treachery and Ethnicity," 219-21; Wickramasinghe, Sri Lanka in the Modern Age, 48; Sivasundaram, "Ethnicity, Indigeneity, and Migration," 218-9; Biedermann and Strathern, Sri Lanka at the Crossroads.

11 Wickramasinghe, Sri Lanka in the Modern Age, xvii, xix.

12 Biedermann and Strathern, Sri Lanka at the Crossroads.

13 Roberts, Sinhala Consciousness; Strathern, "Treachery and Ethnicity."
14 Sivasundaram, Islanded, particularly his observations on how colonial knowledge production and subsequent identification processes came in different waves for the different temporal spaces (e.g., the long-independent Kandyan highlands in comparison to the early-to-be-colonised southwestern coastal regions) is worth pointing out in regards to this study. Also see Schrikker, Expansion and Reform.

15 Rupesinghe, "Navigating Pluralities"; "Do You Know the Ninth Commandment?"

16 Jayasuriya, "Trading on a Thalassic Network"; Schrikker and Ekama, "Through the Lens of Slavery"; Ricci, Banishment and Belonging; Wickramasinghe and Schrikker, "The Ambivalence of Freedom"; Schrikker and Wickramasinghe, Being a Slave; Wickramasinghe, Slave in a Palanquin.

17 Brubaker and Cooper, Colonialism in Question, 59, 71, 89.

18 See specifically: Bayly, "The Pre-History of 'Communalism'?," 177; Bayly, Caste, Society and Politics; Washbrook, "The Colonial Transition"; Talbot, "Inscribing the Other," 692-4; O'Hanlon, "Social Identities in Flux," 102-3; Guha, Beyond Caste, 143-5. Additionally, in the same study Guha explicitly states (2) that he set out to highlight the fact that "the bounded, status-ranked ethnic community or 'caste' is a social form that frequently appears in multi-ethnic societies." A similar understanding of such communities can be of great use to understand the interactions and classifications of Sri Lanka's (early) modern communities; see also Wickramasinghe, Sri Lanka in the Modern Age, xiv-xix.

19 The year 1766 marked the end of the war between the independent kingdom of Kandy and the VOC, which resulted in a further intensification of the Company's rule in the coastal areas of Sri Lanka, and in 1796 the British took over power from the Dutch. This time frame allows us to link up directly to the literature on the early British period; 
in addition, after interacting for over a century, by the mid-eighteenth century the VOC and the island's inhabitants must have had a relatively sharp image of each other.

20 Raben, "Ethnic Disorder in VOC Asia," 117.

21 See Wickramasinghe, Sri Lanka in the Modern Age.

22 De Silva, A History of Sri Lanka, 122-3.

23 Ibid.; Schrikker, Dutch and British Colonial Intervention, 45-7.

24 Schrikker, 22-3. For a study on how these changes affected peasant communities, see Dewasiri, The Adaptable Peasant.

25 De Silva, A History of Sri Lanka, 189-91; Dewasiri, The Adaptable Peasant, 57.

26 Raben, "Batavia and Colombo," 260.

27 Ibid.

28 Ibid., 261.

29 Raben, "Ethnic Disorder in VOC Asia."

30 NA 1.04.02/9945.

31 Ibid.

32 The Dutch had to deal with the language barrier between the Tamil-speaking north and the Sinhala-speaking south from the beginning of their activities on the island, for example publishing all the colonial laws in both Sinhala and Tamil. As such, the language-related division was one which actively influenced Dutch policy. See Schrikker, Dutch and British Colonial Intervention, 41-3, 46.

33 This sample of the last three decades of the Company's rule in Sri Lanka enables us to make potential comparisons with the much more extensively studied (ethnic) categorisations of the British period. In addition, we opted for every first and last missive of the respective governors, as every "new" governor would show us a more generalised image due to their potential inexperience and every "leaving" governor would be most embedded in the discourse. In the end the following missives were studied: NA 1.0.02/9944-45; 9946; 9994-95; 9996; 10012; 10029; 10048.

34 NA 1.04.02/10012.

35 Ibid.
36 Similar to what is described by Raben, "Batavia and Colombo," 260.

37 Rogers, "Early British Rule," 630.

38 Strathern, "Treachery and Ethnicity," 218-9.

39 Based on Portuguese notions of the ethnic/societal composition of Sri Lanka, this stereotypical division was not only crude but also wrong, as families who had lived on the island for uncountable generations were as such considered to be "foreign"; see Raben, "Batavia and Colombo," 248. Both striking and confusing at the same time here is the Dutch nomenclature for Tamils, namely "Malabars," which suggests a connection to India even though it refers to the western Malabar Coast, additionally perplexing considering the first Dutch colonial activities in India were actually focused on the eastern "Coromandel coast," present-day Tamil Nadu.

40 See for example some of the missives that were included in this study, as listed in note 33.

41 Serrão, "Portuguese Land Policies," 183 96. Also see Mottau, "Documents on Ceylon History"; Paranavitana, Land for Money.

42 Dewasiri, The Adaptable Peasant, 4-7, 108-9.

43 See for a more detailed introduction into the lēkam miti: Abhayawardhana, Lēkam Miti Vimarshanaya.

44 de Silva, "The First Portuguese Revenue Register"; Serrão, "Portuguese Land Policies," 189-93.

45 The first Portuguese tombo was a literal translation of the last lekkam miti of the kingdom of Kotte; see de Silva, "The First Portuguese Revenue Register."

46 The Dutch mostly spelled thombos with an 'h.'

47 Schrikker, Dutch and British Colonial Intervention, 33-5.

48 Ibid.

49 Van den Belt, Kok, and Mandemakers, "Digital Thombos," 481-9.

50 For a more detailed description of the Dutch thombos, see Mottau, "Documents 
on Ceylon History"; Paranavitana, Land for Money; Van den Belt, Kok, and Mandemakers, "Digital Thombos"; Bulten, "Reconsidering Colonial Registration."

51 The Dutch word for this communal denominator was geslagt (modern spelling geslacht), which in the context of the early modern period is best translated as "kind."

52 If another family member had a different communal or service-related classification, then that would be added to the respective entry of that family member. In fact, this rarely happened in regards to the communal denominator, as it seems relatively little communal intermarriage took place (or was registered), but differing service classifications were relatively common.

53 The choice to look at the head thombos of two rural Kōralēs (subdistricts) of the Colombo district was twofold. Firstly, the registers of these two regions were already entered in a readily available database used for earlier research. Secondly, and more importantly, we hypothesised that looking at the categorisation of local agents in the rural hinterlands would further highlight the importance of the locale and goal at the moment of categorisation when it comes to the categories used in the different colonial documents and archives.

54 The descriptions of the different castes and their general features had to be significantly simplified for the sake of space. For a much more detailed consideration of the different caste-groups found in southwestern Sri Lanka in the eighteenth century, see Dewasiri, The Adaptable Peasant.

55 Granted that in the areas that received more migrants from other parts of South Asia, such as the suburbs of Colombo and Negombo, both the categories Sinhalese and Mallabar (e.g., Mallabar silver smith) were recorded in the thombos for those areas.

56 There are some exceptions, like the renters within the system of tax farming, which was accessible to any person as long as they were able to bid during auctions for these administrative positions.

57 Since at least the Portuguese period, communities like the originally South Indian Chetties and the Muslim communities known as Moors were considered frosteros (foreigners). It is no coincidence that a fair share of members of both groups were merchants, and thus considered competitors by both the VOC and the Portuguese before them. See Raben, "Batavia and Colombo," 225-30. This custom, however, could be much older, as Moors in the independent territories belonging to Kandy also had to perform uliyam.

58 One male member per family had to perform one month's worth of hard labour per year, or pay a certain fee in cash instead.

59 These conflicts are numerous in the correspondences, petitions, and ordonnances sent back and forth between the Landraad and the population of the colonial hinterlands; see e.g. Sri Lankan National Archive, Colombo (SLNA) 2466.

60 As they also continued to exist in the independent kingdom of Kandy, see Pieris, Sinhalese Social Organization.

61 Rupesinghe, "Negotiating Custom," 4551; In some cases people even sent requests to the Landraad to have their lands measured, or resurveyed, if they felt the commissioners had missed lands before; see e.g. SLNA 1/3670: "[the native commissioners] have been ordered to visit and measure the gardens in the Panturian district, as per request from the local inhabitants."

62 Rupesinghe, "Negotiating Custom," 4551; Bulten, "Reconsidering Colonial Registration".

63 See Benton, Law and Colonial Cultures.

64 See Anderson, Subaltern Lives, 6-7.

65 Rupesinghe, "Negotiating Custom," 17. See also Schrikker, "Conflict Resolution."

66 Schrikker, "Conflict Resolution," 230; Rupesinghe, "Negotiating Custom," 26. 
67 We are of course aware of the fact that it is complicated to reconstruct whose "voices" we are hearing in the documents. Everything was recorded and signed by a clerk; as such the clerk presents the problem of the broker of information.

68 Obviously the civil cases showcase some of the more ordinary social situations encountered by the more ordinary people in society than the criminal cases would; however, their appearance in the colonial archive on its own suggests a break from the "normal," and as such we are not under the illusion that we will describe the "everyday lives" of the common people. However, it does give us a chance to grasp those who were otherwise silent in the colonial records. See also the idea of the "normal-exceptional" in Ginzburg, The Cheese and the Worms.

69 SLNA 1/4194-4547.

70 One could also argue that the "moors" were identified by more than religion alone, as the Company (and other colonial entities preceding and succeeding the VOC) considered them as a distinct social group. See Raben, "Batavia and Colombo"; McGilvray, "Arabs, Moors and Muslims."

71 See Rogers, "Post-Orientalism."

72 A general category of "Moors" was used throughout the Dutch documents, with no distinctions found between those who had been settled on the island for centuries compared to potentially more mobile Muslim traders from India (in the 1911 census specifically marked as "coastal" or Indian Moors); see McGilvray, "Arabs, Moors and Muslims."

73 Originally thought to be a Tamil-speaking class of merchants with extensive connections in India. See Wickramasinghe, Sri Lanka in the Modern Age, 139, 173-74; Raben, "Batavia and Colombo," 237, 248-51.

74 There were 41 cases with at least one Chitty defendant or plaintiff out of 203, so about $20 \%$.
75 Raben, "Batavia and Colombo," 237, 248-51; Wickramasinghe, Sri Lanka in the Modern Age, 139, 173-4.

76 In a 1778 case before the Council of Justice in Colombo between Chetty merchants, six witnesses were called upon from Tamil Nadu, up to 500 kilometers away. This suit will be discussed in more detail in an upcoming article on cross- (and cross-cultural) examinations before Dutch civil courts in Sri Lanka. SLNA 1/4458: Wiereragewen Modliaar v. Aroenaselen Modliaar.

77 Unpublished database on witnesses called upon by the Council of Justice. In 1743 for a specific suit, nine Chetties were interrogated, and eight of them said to be of Roman Catholic faith. SLNA 1/ 4216: Donna Cicilia, widow of the native physician, Pedro Jurie Ondaatje, contra the Chittys and Parruas "boedelmeesteren" of Colombo and others.

78 Chetties acting as witnesses in SLNA 1/ 4376-4377, and SLNA 1/4434, in particular, self-identified as Roman Catholics.

79 In one particular case the Civil Council commented on a dispute between two Chetties, mentioning that they had first consulted an oracle, as the "heathens" (in this case the Chetties), supposedly always did, thus implying a certain common characteristic of this group. At the same time the Civil Council accused the creditor of having a childlike understanding of the laws surrounding debt, and they were of the opinion that he had some strange beliefs: SLNA 1/4402-3.

80 To complicate matters even more, Raben mentions the existence of another group of South Indians, mostly composed of people freed from enslavement in the seventeenth century, who were from a very different social stratum than the other "Chetties," but were still categorised as such by the Company officials. Raben, "Batavia and Colombo," 249.

81 E.g., SLNA 1/4349; 4350; 4351-2; 4375; 4376-7; 4394-9. 
82 SLNA 1/4427.

83 Raben, "Batavia and Colombo," 249.

84 Yet another example (besides SLNA 1/ 4458; see note 76) can be found in a civil case which started 19 July 1769 , when the representative of a merchant identified as a Chetty from South India had come to the Council to bring forward a dispute between the merchant and a local headman (a mohandiram) about a bond of fifty-five pagoda coins. The South Indian Chetty had allegedly loaned this money to the headman in 1766, after which another representative, a "Moorish" trader, had brought the headman the bond in 1769. The headman denied ever receiving this bond, and thus did not settle the debt: SLNA $1 / 4363$.

85 Where a South Indian merchant, identified as a "Chetty," had come to Sri Lanka, presumably on business, and had consequently loaned money to a Sri Lankan headman. This loan was then supposed to be returned to him through a bond presented by a "Moor" trader, which had failed and as such concluded with a court case in Colombo where another representative of the merchant had appeared in front of the colonial administration.

86 SLNA 1/4201.

87 The addition "nainde" refers to a farmer of lower caste who performed menial chores as required service to the VOC, such as transporting cinnamon. Wagenaar, Galle, 165.

88 For a particularly fascinating case study of litigants on the colonial crossroads of indigenous and European socio-legal worlds, see Lyna, "Ceylonese Arcadia."

89 Raben, "Batavia and Colombo," 260; Wickramasinghe, Sri Lanka in the Modern Age, 48.

90 Rogers, "Early British Rule," 630.

91 For example, where most families in majority Sinhalese regions were recorded in the thombos according to caste, in some of the more mixed and diverse regions (like the neighbourhoods close to the forts) some families were just recorded as "Sinhalese." See for example the more "diverse" region near the Colombo fort: SLNA 1/3758, versus the majority Sinhalese hinterland region of Siyane: SLNA 1/3739. Additionally, the thombos were created with the help of dozens of native commissioners and clerks, and the registration process was marked by constant negotiations between the registrar and those registered.

92 See Szreter, Sholkanmy, and Dharmalingam, Categories and Contexts; Breckenridge and Szreter, Registration and Recognition.

93 Schrikker and Lyna, "Threads of the Legal Web."

94 Sivasundaram, "Ethnicity, Indigeneity, and Migration," 430. See also Sivasundaram, Islanded. 